\title{
What Leads InTERnational Organizations in Latin America to be Active or Paralyzed? A Qualitative Comparative ANALYSIS
}

\author{
¿Qué lleva a las organizaciones regionales de \\ América Latina a estar activas o paralizadas? Un \\ Análisis Comparativo Cualitativo
}

DOI: $10.4067 /$ S0718-090X2022005000103 VOLUMEN 42 / No 1 / 2022 / 55-80 ISSN: 0718-090X Revista de Ciencia Política cienciapolitica.uc.cl

\section{MARIANA LYRA}

Universidade da Integração Internacional da Lusofonia Afro-Brasileira, Brazil

\section{MIKELLI RIBEIRO}

Universidade Federal de Pernambuco, Brazil

\begin{abstract}
This article seeks to identify the conditions that lead Latin American International Organizations (IOs) to remain active or to paralize. It surveys various elements identified by IO literature that accounts for the IOs activity/paralysis and applies Qualitative Comparative Analysis to search for configurations that explain the outcomes. By exploring $31 \mathrm{IOs}$ in the Americas, the analysis shows that adequate staff is crucial for an IO to maintain regular activities in the region. High-quality staff and large teams are sufficient to keep regular operations, with the possible tradeoff either by restricting IOs' scope or having a high number of member states. Conversely, we found that a more complex combination of institutional features and external aspects is needed for Latin American IOs to paralyze. Small teams and diminished political autonomy combined with low levels of statehood and member states that contest the organizations proved to be a consistent path to drive IOs not to operate regularly.
\end{abstract}

Keywords: Latin American Organizations, Institutional Paralysis, Regionalism, QCA.

\section{RESUMEN}

Este artículo busca identificar las condiciones que llevan a las Organizaciones Internacionales (OIs) latinoamericanas a permanecer activas y qué caminos causales las llevan a la parálisis. Por lo tanto, este estudio evalúa condiciones y combinación de condiciones señaladas por la literatura mediante el uso de Qualitative Comparative Analysis (QCA). Esta investigación explora 31 OIs en las Américas. Los resultados muestran que tener personal adecuado es fundamental para que una OI tenga actividades regulares en la región. Tener personal de alta calidad y un gran equipo son suficientes para mantener las operaciones regulares, con la posible compensación sea restringiendo el alcance de las OIs o teniendo 
un gran número de estados miembros. Por el contrario, se encontró que se necesita una combinación más compleja de características institucionales y aspectos externos para que ocurra la parálisis de una OI. Equipos pequeños y autonomía política disminuida combinados con bajos niveles de statehood y estados miembros que se oponen a las organizaciones demostraron ser un camino consistente para que las OIs no operen con regularidad.

Palabras Clave: Organizaciones Latinoamericanas, Parálisis Institucional. Regionalismo. QCA.

\section{INTRODUCTION}

International Relations (IR) analyses are abundant in the study of International Organizations (IOs), especially with regard to their importance, institutional designs, and role in international relations. However, studies on the factors that lead IOs to work regularly or to stop working are still relatively scarce, especially in mainstream IR (Dijkstra 2019; Eilstrup-Sangiovanni 2020). In a seminal study in the 1970s, Wallace and Singer (1970) systematized an overview of IOs from 1815 to 1964 . In the late 2010s, the growth of research on why International Organizations decline/survive is noticeable (Debre and Dijkstra 2021; Dijkstra 2019; Eilstrup-Sangiovanni 2020; Gray 2018). Research on the theme is methodologically diverse, leading to different conclusions. In the 1990s, analyses were predominantly qualitative, while in the 2010s there is an increase in large-n empirical research. Many of the recent studies have performed extensive analyses, using different research designs, such as survival analysis, standard gravity model, and cross-sectional analysis (Debre and Dijkstra 2021; Eilstrup-Sangiovanni 2020; Gray 2018). In common, most of these studies disregard regional components, but the geographic context can play an important role, since "states often cooperate in and through regional organizations" (Panke and Starkmann 2021: 02).

Specifically, regarding Latin America, there are still few studies seeking to understand the elements that lead regional organizations to work/stop working. Discussions on the topic are often mixed with regionalism and regional integration. Furthermore, such studies lead to different results from global ones on what factors contribute to the functioning/non-functioning of IOs. This paper seeks to fill that gap in Latin American literature. It aims to shed light on that matter by identifying what conditions - or combinations thereof - explain the regular functioning of IOs or lead them to paralysis. Hence, the research analyzes 31 regional organizations in the American continent - 21 Latin American International Organizations and 10 Hemispheric IOs.

Research on the theme has often reached different results (both globally and in Latin America); thus, it is assumed that the underlying reasons for IOs to work or to stop working are conjunctural. Strictly speaking, the outcome can be achieved by different sets of factors, and it is necessary to evaluate the main elements pointed out in literature for the Latin American case. To do so, the 
paper uses Qualitative Comparative Analysis (QCA), which is applied to understand contexts of causal complexity (Ragin 2008; Schneider and Wagemann 2012). This methodological approach turns out to be particularly relevant in this analysis due to some of its inner characteristics: conjunctural causation, equifinality, and asymmetrical causation.

Covering $96 \%$ of the cases, the findings related to outcome occurrence show that adequate staff is a key factor for maintaining IOs active in the region. In other words, having high-quality staff and a large team is sufficient to keep regular operations. The lack of adequate bureaucracy may be compensated either by restricting IOs' scope or by having a high number of member states. Conversely, we found that a more complex combination of institutional features and external aspects is necessary to explain the paralysis of the Latin American Organizations.

This paper is organized as follows. The second section discusses theoretical propositions for vitality/paralysis of International Organizations. The third section debates methodological choices and research design. Then, the fourth section presents conditions, outcomes and cases. Finally, the fifth section discusses the results found.

\section{INTERNATIONAL ORGANIZATIONS: BIRTH, GROWTH, AND DECLINE}

In the 20th Century, one could testify to the proliferation of IOs, broadening scope in terms of performance, thematics, geographical presence, and types of members. This analysis focuses on International Intergovernmental Organizations, defined as institutions with more than two members (hence excluding bilateral institutions), which develop at least one plenary session every ten years and with a physical address or permanent secretariat ${ }^{1}$ (Pevehouse, Nordstrom, and Warnke 2004).

In the discipline of International Relations (IR), several theories and approaches have sought to understand the creation and functioning of IOs, emphasizing their role in contemporary international politics. Mainly, mainstream theories of IR provide a powerful framework to analyze IOs in general. Notably, Liberal Institutionalists (Keohane 2005; Pevehouse, Nordstrom, and Warnke 2004), Constructivists (Barnett and Finnemore 2004; Finnemore 1996), and Neofunctionalists (Haas 1964) have spent considerable time seeking to understand IO roles in international politics. Realists are the exceptions, since they see IOs as only an epiphenomenon of States relations (Mearsheimer 1994). Nevertheless,

Regarding these last elements, by following Pevehouse, Nordstrom, and Warnke 2004, we consider the absence of a physical address supplemented by having permanent secretariat. Organizations such as The Pacific Alliance has permanent secretariat even though they lack a physical address. Unasur opened its headquarters in 2014, despite having had a secretariat since 2010. 
these theories are not specifically committed to identify the factors that make international organizations keep regular activities and those that lead them to paralyze. Nonetheless, in the late 2010s, Dijkstra (2019) and Debre and Dijkstra (2021) made important efforts to build an institutional theory about the life, decline, and death of international organizations. In order to identify these variables, rather than looking into broad theoretical approaches, it is necessary to address more fine-grained literature.

One of the first attempts to understand these specific phenomena came from the Wallace and Singer (1970) study. They identified factors that mark the end of an International Organization: (1) ten consecutive years without a plenary meeting with members, and (2) when an IO is succeeded or replaced by another. The authors did not set out to test hypotheses, but to organize the "first systematic effort to generate this data, so that we may move on in a cumulative fashion toward the empirical testing of propositions, models, or theories" (Wallace and Singer 1970: 239).

From the 1990s onwards, we observe an increasing number of studies in the discipline of IR to understand why International Organizations endure. Based on a qualitative research design, Gallarotti (1991) lists four factors that constrain IO performance, leading to mismanagement of international relations and, therefore, the loss of relevance. "Attempts to manage complex, tightly coupled systems" is the first fault, since complex issues are challenging to understand, hindering articulations for successful management. In Gallarotti's study, IOs' scope is a fundamental factor to understand institutional vitality. The second failure is when IOs propose "solutions to discourage nations from pursuing more substantial or long-term resolutions to international problems" (Gallarotti 1991: 192), because it can reduce incentives for States to participate in presenting alternatives. Also, IOs can "intensify international disputes under several circumstances" because they tend to provide more legitimacy to one side of the conflict, altering the balance of power in moral terms (Gallarotti 1991, 193). IOs might be "a source of moral hazard" as they "reduce the incentives for the state to eliminate the underlying problem, which is the behavior itself" (Gallarotti 1991, 193). Therefore, a broad scope of actions, leading roles in solving problems to the detriment of the States, the possibility of intensifying international disputes, and moral hazards are pointed out as the main factors that limit IOs' functioning.

Relevant academic contributions boosted the literature on international organizations vitality, and Eilstrup-Sangiovanni's work is one of them. She evaluates possible elements that lead to the end of International Organizations. Similar to Gallarotti (1991), Eilstrup-Sangiovanni (2020) argues that the variable scope plays a significant explanatory role. However, Eilstrup-Sangiovanni (2020) added another explanatory component: membership. According to the author, IOs with broad functions and global membership have a higher survival rate than those with a medium scope and restricted regional range. This is probably due to the adaptive capacity and the reduced vulnerability to shocks that 
the diversity of members and the functional range can provide to an IO (Eilstrup-Sangiovanni 2020). Moreover, in her survival analysis of International Organizations from 1815 to 2015, the author also finds that (1) IOs decline is strongly correlated to geopolitical conflicts, and (2) technical organizations are more likely to survive than other types of IOs. Results are based on cross-sectional and survival analysis, which combined five variables: number of participants, membership, mandate, region, and organizational scope.

These studies reported evidence that survival and death of IOs are not related to a single dominant cause, but to different combinations of factors that lead to the same result, which can change over time, taking into account contextual elements such as changes in the balance of power and geopolitical conflicts (Eilstrup-Sangiovanni 2020). This does not mean that the decline of IOs is the result of randomness, but several causal paths may lead to the death of an international organization.

Another particularly relevant study to assess the decline of IOs was performed by Dijkstra (2019). He tries to outline "an institutional theory on the decline and death of international organizations" (Dijkstra 2019: 08). The author highlights the advances in the study of institutional design and the development of organizations, but points out the lack of research on the decline and end of IOs.

IOs suffer external pressures; however, they are endowed with different degrees of institutional adaptation and resistance, in which: (1) flexible IOs are more likely to outlive less-flexible IOs, and (2) larger IOs are more likely to outlive smaller ones. These variables would be essential for the survival of international organizations, as they would allow IOs to adapt to external changes, increase the costs of member states to create/replace an existing $\mathrm{IO}$, and bureaucratic staff could act as active players in the search for survival. By testing this hypothesis, after survival analysis of a sample of IOs during 1815 and 2014, Debre and Dijkstra (2021) added a new factor that would explain IOs' death. According to them, "the most important variable explaining death of IOs is the size of the secretariat staff" (Debre and Dijkstra 2021:312). Additionally, they found that "diverging preferences among member states and the degree of institutionalization can explain the replacement of IOs", and "systemic and domestic factors do not explain IO failure" (Debre and Dijkstra 2021:311). The latter result contrasts with Latin American literature, which states that the most relevant variable for the limited role of regional international organizations - as a more profound consequence of regionalism - is the result of internal characteristics of Latin American states, such as limitations of state-building and complex socio-political-economic issues (Buelvas 2013; Garcés Velástegui 2017).

Another relevant study also concluded that IO staff plays a crucial role in explaining IO vitality. However, instead of focusing on its size, Gray (2018) identifies staff quality as the key element. She also indicates a second variable: political autonomy. According to Gray (2018), the organization's vitality is positively associated with its ability to attract and retain talent, and to greater autonomy 
for IO to enact policies. In addition, she finds a positive correlation between the organization's death and more complex proposals for integration, such as the European Union.

Gray's (2018) study is also important because it elucidates that the analysis of institutional design alone does not seem to be enough to understand the causes of IOs survival/decline, since organizations "may seem impressive on paper, but if their bureaucracies are not empowered to make decisions or if they cannot attract good staff, they may persist in a comatose state or die altogether" (Gray 2018:02). This research innovates by indicating the insufficiency of binary classifications (active/inactive, alive/dead etc.), proposing to categorize IO vitality in three different states: vitality, zombie and death. Organization's vitality is attributed when it is working, with at least one internal meeting per year. Zombie organizations are those with intermittent operation, with production below expectations, and they usually try to renew under another name. Dead organizations refer to those with formal secretariats and bureaucracies that do not join in meetings or show any activity level.

Most studies on IOs do not pay much attention to regional idiosyncrasies. Eilstrup-Sangiovanni (2020) shows that, during 1815 and 2015, the European IOs were seven times more likely to end than global ones, while the probability decreased to 6 times for American and African IOs. However, she does not elaborate on explanations for regional differentiation. Hence, the study of regional international organizations is important, as it can reveal specific local patterns.

Apart from the more general literature on IOs, the specific scholarship on regionalism also seems to be presenting some explanations for regional IO success or failure. After all, the formation of regional IOs is linked to regionalism (Petersen and Schulz 2018). In a provocative article, Malamud and Gardini (2012) ask 'has regionalism peaked?' to analyze the trends of Latin American regionalism and its supposed quagmire. They argue that traditional economic integration arrangements seem to have reached their limit, creating a scenario of stagnation, competing membership, and poor institutional commitment. In this sense, the Latin American regionalism has changed in a world scenario of increasing bilateral agreements and the emergence of geographically diffuse multilateral arrangements, not meaning the end of regionalism in Latin America, but its transformation.

Latin American regionalism is also seen from the perspective of consolidating state capacity, in which Latin American governments use regionalism to reinforce domestic agendas at the expense of building solid institutions (Petersen and Schulz 2018). Latin American States deliberately avoid engaging in the construction of pooled sovereignty and the development of regional organizations as effective centers for the promotion of public goods. Therefore, the lack of political autonomy of regional IOs - often conditioned to the aspirations of Latin American governments - would lead to their fragility and paralysis. 
Contrastingly, regionalism in Latin America may also be a "wicked problem" (Garcés Velástegui 2017), an interweaving of social, political, economic and cultural issues that prevent regionalism from moving towards more robust regional integration stages, and hamper the consolidation of regional organizations. Although it is an interesting reasoning, it does not offer a detailed view of factors that hinder the progress of Latin American collective arrangements.

Another study called attention to a different variable to be considered while evaluating regional IOs in Latin America: the level of statehood. ${ }^{2}$ Buelvas (2013) specifically points to the "Lack of Stateness" as a causal mechanism for the fickleness of regionalism in the subcontinent since the weaknesses of state-building "have limited the development of regional ties necessary to advance to a 'deeper' regionalism" (Buelvas 2013:444). Although Buelvas (2013) is referring specifically to regionalism and integration projects, it is possible to extrapolate that "deeper regionalism" involves some level of support from regional organizations, so it is a hypothesis that needs to be evaluated. However, when taking into account general studies on IOs, the probability of IO survival in the Americas is higher than in Europe (Eilstrup-Sangiovanni 2020), a region with higher levels of stateness than in the American continent. ${ }^{3}$ Furthermore, Debre and Dijkstra (2021) have not found any evidence that domestic factors explain the decline of IOs.

Overall, when the scholarship on Latin American regionalism tried to explain the difficulties of deeper results - which can be translated into functioning regional organizations - they produced different results than global research (Malamud 2019; Malamud and Gardini 2012; Quiliconi and Espinoza 2017).

The idea of this section was to pinpoint factors in the IOs and regionalism literature that seek to explain Latin American IOs' activity or paralysis. In the following sections, we evaluate how these factors interact, creating pathways to the referred outcomes. We use QCA methodological framework to build models that would account for these interactions.

\section{METHOD AND RESEARCH DESIGN}

The study of International Organizations is vast in analyzing institutional designs, but it is still beginning to grasp the factors that lead IO to survival

\footnotetext{
Buelvas (2013) uses the concept of stateness proposed by Zaytsev (2013), which is based on four dimensions: resource mobilization capacity, external sovereignty, maintenance of internal order, and state activism in regulatory, economic and social issues. We understand that statehood - defined as "a phenomenon that is made up of three distinct, though interrelated, dimensions: state authority, state capacity and state legitimacy (ACL)" (Grävingholt, Ziaja, and Kreibaum 2012:06) - can be used as an indicator of levels of stateness.

Nevertheless, it should be noted that in Eilstrup-Sangiovanni's study of regional organizations she considered the American continent as a whole, with no divisions between the Latin American IOs and the Hemispheric organizations.
} 
or decline. As presented in the previous section, research on the factors that lead to survive/decline has produced different results. According to the general literature on IO, the following elements are important for the functioning/ non-functioning of IOs: scope (Eilstrup-Sangiovanni 2020; Gallarotti 1991), number of states (Eilstrup-Sangiovanni 2020), size of the secretariat staff (Debre and Dijkstra 2021), quality of staff (Gray 2018), and IOs political autonomy (Gray 2018). Specifically, political autonomy (Petersen and Schulz 2018) and the lack of stateness (Buelvas 2013) have been highlighted from the literature on Latin America.

It is important to note that, as Eilstrup-Sangiovanni (2018) argues, the survi$\mathrm{val} /$ decline of an IO is context-dependent, and there is no sole explanatory cause that leads an organization to work/stop working. It is not an ahistorical process, displaced from the socio-political dynamics in which international organizations are inserted. It is fundamental to understand that several causal paths sustain IOs' regular activities, or may lead them to paralysis.

This paper applies Qualitative Comparative Analysis (QCA) to 31 cases, as detailed in Table 1. This approach is appropriate because literature points to different conditions which would lead to the outcome studied. Some of these conditions may have explanatory power only when combined with each other (conjunctural causation). QCA model may unravel this pattern. Secondly, instead of searching for a single explanation, QCA permits to evaluate whether these different conditions could actually translate into different non-exclusive pathways that could explain the same outcome: active/paralysis (equifinality). Finally, the absence of elements that may explain why an organization remains active may not necessarily be the explanation for paralysis. By using QCA, it is possible to identify different non-symmetrical paths to opposite outcomes (asymmetrical causation) (Schneider and Wagemann 2012). Additionally, despite being a qualitative study, this research has a relatively high number of cases for within-case analysis. QCA is a method suited to analyze a qualitatively broader number of cases (medium-N) and still grasp qualitative explanations (Ragin 2008). QCA seeks to answer which conditions or set of conditions are necessary and/or sufficient for a given outcome. For methodological acuteness, from now on, the variables identified in the previous section will be referred to as conditions. $^{4}$

"Causality in QCA is expressed as conditions being sufficient or necessary for the outcome, not in terms of independent variables having an effect on a dependent variable. That is, QCA focuses on the causes of effects, rather than the effects of causes" (Rubinson 2019:02). 
Table 1 - Cases: List of Regional Organizations

\begin{tabular}{|c|c|c|c|c|}
\hline Acronym & Organization Name & $\begin{array}{c}\mathrm{IO} \\
\text { Start } \\
\text { Date }\end{array}$ & $\begin{array}{l}\text { Number } \\
\text { of Member } \\
\text { States }\end{array}$ & Location \\
\hline OPANAL & $\begin{array}{l}\text { Agency for the Prohibition of Nuclear Weapons in } \\
\text { Latin America and the Caribbean }\end{array}$ & 1969 & 33 & Mexico City \\
\hline ATCO & Amazon Cooperation Treaty Organization & 1978 & 8 & Brasilia \\
\hline Andean & Andean Community & 1970 & 4 & Lima \\
\hline $\mathrm{AP}$ & Andean Parliament & 1980 & 5 & Bogota \\
\hline ASBLAC & $\begin{array}{l}\text { Association for the Supervision of Banks of Latin } \\
\text { America and the Caribbean }\end{array}$ & 1981 & 33 & Mexico City \\
\hline BS & Bank of the South & 2007 & 6 & Caracas \\
\hline CAIPA & $\begin{array}{l}\text { Central American Institute for Public Adminis- } \\
\text { tration }\end{array}$ & 1954 & 6 & San Jose \\
\hline SICA & Central American Integration System & 1991 & 27 & San Salvador \\
\hline COSAVE & Comité de Sanidad Vegetal & 1991 & 7 & Asuncion \\
\hline IACI & Inter-American Children's Institution & 1927 & 34 & Montevideo \\
\hline IACSS & Inter-American Conf. on Social Security & 1942 & 33 & Mexico City \\
\hline IADefB & Inter-American Defense Board & 1942 & 24 & $\begin{array}{l}\text { Washington } \\
\text { DC }\end{array}$ \\
\hline IAIAS & Inter-Am Institute of Ag. Science & 1942 & 34 & Turrialba \\
\hline IAIC & Inter-Amerjca Investment Corporation & 1986 & 36 & $\begin{array}{l}\text { Washington } \\
\text { DC }\end{array}$ \\
\hline IATTC & Inter-American Tropical Tuna Commission & 1950 & 14 & San Diego \\
\hline ICRPBC & Intergov. Committee of the River Plate Basin & 1969 & 5 & Buenos Aires \\
\hline LACP & Latin American Center for Physics & 1962 & 14 & Rio de Janeiro \\
\hline LACAC & Latin American Civil Aviation Commission & 1973 & 22 & Lima \\
\hline SELA & Latin American Economic System & 1975 & 28 & Caracas \\
\hline LAIEC & $\begin{array}{l}\text { Latin American Institute of Educational Commu- } \\
\text { nication }\end{array}$ & 1978 & 13 & Mexico City \\
\hline LAEO & Latin American Energy Organization & 1973 & 27 & Quito \\
\hline LAFDO & $\begin{array}{l}\text { Latin American Fisheries Development Organi- } \\
\text { zation }\end{array}$ & 1982 & 19 & Lima \\
\hline LAIA & Latin American Integration Association & 1980 & 12 & Montevideo \\
\hline PAIGH & Pan American Institute of Geography and History & 1928 & 22 & Mexico City \\
\hline PAHO & Pan American Health Organization & 1902 & 35 & $\begin{array}{l}\text { Washington } \\
\text { DC }\end{array}$ \\
\hline OAS & $\begin{array}{l}\text { Pan American Union/Organization of American } \\
\text { States }\end{array}$ & 1890 & 35 & $\begin{array}{l}\text { Washington } \\
\text { DC }\end{array}$ \\
\hline Mercosur & MERCOSUR & 1991 & 6 & Montevideo \\
\hline Unasur & Union of South American Nations & 2008 & 12 & Quito \\
\hline Alba & $\begin{array}{l}\text { Bolivarian Alliance for the Peoples of Our Amer- } \\
\text { ica }\end{array}$ & 2008 & 6 & Caracas \\
\hline PA & The Pacific Alliance & 2011 & 4 & - \\
\hline CELAC & $\begin{array}{l}\text { Community of Latin American and Caribbean } \\
\text { States }\end{array}$ & 2010 & 33 & Caracas \\
\hline
\end{tabular}

There are some forms of QCA. This paper has employed fuzzy-set QCA (fsQCA), which makes it possible to analyze nominal, ordinal, or interval condi- 
tions through calibration in degrees. Calibration is "the process of using empirical information on cases for assigning set membership to them." (Schneider and Wagemann 2012:32) It is important to note that fsQCA can combine conditions with a binary calibration (crisp) and those calibrated as fuzzy. This paper followed Basurto and Speer (2012) guidelines to calibrate the conditions.

We evaluate ${ }^{5}$ the possible effects of the following conditions: organizational scope, quality of staff, number of states, statehood level, degree of political autonomy, staff size, lack of a dominant power, and contestation. In QCA, the process of choosing conditions needs to be in accordance to prior literature/theory. It is a theory-driven approach; conditions need to make sense to be evaluated (Schneider and Wagemann 2012). As presented in the previous section, six out of these eight conditions were found in the literature. QCA also has an interactive procedure to adjust ideas and evidence. There is the need to "engage in a back-and-forth between prior knowledge and cases" (Thomann and Maggetti 2020:10). New conditions (and/or cases) may be added (or subtracted) by exploring other theoretical venues - that was the case for conditions 'lack of a dominant power' and 'contestation'.

We built our empirical data from existing datasets, representing the last year (2019) of available information and collected from several sources, such as COW IGO dataset.17, Yearbook of International Organizations, the US State Department, Grävingholt, Ziaja, and Kreibaum (2012), Fragile States Index 2019 , direct consultation with IO, and organization websites. Some conditions required calibration; depending on the condition, they are calibrated as crisp ( 0 or 1) or fuzzy (calibration in degree).

\section{EXPLANATORY CONDITIONS, OUTCOME AND CASES}

Based on the literature in section one, we deduced six conditions ${ }^{6}$ to be evaluated by using QCA. Condition definitions and operationalization are described in this section. Condition Organizational Scope indicates if the IO is a) narrow, specialized, and generally technical; b) medium-low, develops various activities, but within a specific technical area; c) medium-broad, develops various activities within a political area; or d) broad, deal with various subjects, includes political, economic and security objectives. Data was adapted from

It is worth noting that this paper does not engage in theory-testing. QCA is not usually applied to this type of study due to its intrinsic features, such as the back-and-forth process (Schneider and Wagemann 2012). Rather, it can be used either for theory evaluation purposes (deductively) or to find new hypothesis (inductively). The former is used when the researcher intends to evaluate whether previously hypothesized configurations hold - following a deductive approach. By contrast, the latter focuses on research designs seeking to present new hypotheses and/or refine new ones through an inductive/explorative process (Thomann and Maggetti 2017). Since this article aims to bring new configurations based on the hypotheses previously pointed out by the literature, it follows the second approach.

6 Six conditions is appropriate for the number of cases. Although QCA does not have a "golden rule", the ratio 1 condition for 4 cases is recommended, respecting that internediate-N analysis (10 to 40 cases) could select from 4 to 7 conditions (Berg-SchlosserH et al. 2008; Marx 2010; Schneider and Wagemann 2012). 
Eilstrup-Sangiovanni (2018). Narrow, medium-low, medium-broad, and broad were coded $0,1,2$ and 3, respectively, and subsequently calibrated, where 0 indicates full non-membership, 1.5 is anchor value and 3 is full-membership. Regarding directional expectations, there is no consensus on the association of organizational scope and vitality/paralysis of IOs. In the model, condition was titled CSCOPE.

Condition Size of Staff indicates the size of the bureaucracy in terms of employees. We expect that the size of staff is conducive to IO vitality. IOs with less than 50 employees were coded 0 , and those with more than 50 employees were coded 1 . As the condition is dummy, fuzzy calibration is not applied. The condition is titled STAFF. Information was collected from organizations' websites and direct consultation with IO. Condition Quality of Staff is based on Gray (2018). It uses the percentage of hardship pay associated with working in the host city of IOs secretariat by the US government, in which "a higher premium required to compensate for difficult or undesirable living conditions" (Gray 2018:08). The US government's hardship may imply limitations to the definition of quality of staff, especially since it may reflect patterns of relationships between the USA and other States. However, it is an indicator specifically related to bureaucratic work abroad, and IOs do not provide payment additions according to location. Although it is still underdeveloped in International Relations, the importance of the location as an attraction for qualified professionals is well studied in the field of Human Resources, specifically in the literature of global teams (Mockaitis, Zander, and Cieri 2018). Thus, cities associated with lower hardship pay may attract better professionals, being a proxy indicator of quality of staff. It ranges from 0 to 35.0 indicates full non-membership, 20 is the anchor value and 35 is full membership. The intermediate value (20) indicates the world average of hardship pay remunerated by the US government. It is expected that hardship pay is conducive to IO paralysis. The condition is titled HARDPAY.

Condition Number of States refers to the number of member states of the organization. 3 indicates full non-membership since it is the minimum number for the composition of an IO, 10 is the anchor value for representing half of Latin American countries, and 33 is the full membership. Regarding directional expectations, there is no consensus on the association of the number of member states and vitality/paralysis of IOs. Information was collected from the Yearbook of International Organizations and from the organizations' websites. The condition is titled NSTATES.

Condition Degree of Political Autonomy captures the level of IO autonomy. This ranges from no formal organization to supranational ones. It follows Haftel's (2012) classification in 5 degrees, where an IO is coded 0 if there is no intergovernmental institution; 1 if it has nominal institutions; 2 if the IO performs information gathering and advisory; 3 if it amends proposals; 4 if the IO is able to veto proposals; and 5 if it is a supranational organization that operates as a primary source of decisions. In calibration, 0 indicates the full non-member- 
ship, 2.5 is the anchor value and 5 is full membership. It is expected that the degree of political autonomy is conducive to $\mathrm{IO}$ vitality. The condition is called CPOLAUT.

The Level of Statehood is the only condition exogenous to organizations. Member states of IOs were categorized according to their level of statehood following Grävingholt, Ziaja and Kreibaum's (2012) classification of state fragility ${ }^{7}$. Membership was attributed $0=$ low statehood; 1 = medium-high statehood. For cases in which the authors' classification was not available, the Fragile States Index 2019 was used as a supplement. As the condition is dummy, fuzzy calibration is not applied. It is expected that the level of statehood is conducive to IO vitality. The condition is called STHOOD.

The outcome refers to the dummy condition, in which " 1 " indicates that the IO is active, that is, $\mathrm{IO}$ is functioning, and " 0 " is paralyzed. The idea of paralysis assumed here is also presented in the literature as decline. In this sense, paralysis does not indicate the death or complete disappearance of an IO, but the loss of relevance and capacity for action. Moreover, the concept of paralysis is similar to "zombie organization" proposed by Gray (2018: 1), in which IOs are thus classified when "their offices stay open, and some minimal activity persists, but they make few meaningful advances in cooperation." 'Paralysis' is attributed to those organizations that do not perform activities, summits, declarations, activity reports, action plans (ongoing or proposed) in the past 3 years, but have not yet been formally dissolved; otherwise, the IO is considered as regularly functioning (active).

In general, scholars suppose that the absence of factors leading to the functioning of IOs explain their non-functioning. Given the possibility of asymmetric causation, we have added rival explanation for paralysis: presence of a dominant power/paymaster and contestation. Presence of a dominant power indicates the presence of a paymaster or a dominant power capable of assuming organizational costs. This is not a condition found in the specific literature regarding IO vitality, but an expectation the authors inferred based on a broader scholarship on IOs and Regional Integration (Börzel and Risse 2016; Mattli 1999; Lohaus and Hummel 2012). IOs without a paymaster or dominant power were coded 0 , and those with a paymaster were coded 1 . It is expected that the absence of a dominant power is conducive to IO paralysis. The condition is called POWER. Contestation refers to ideological changes in the governments of member states, which lead to resistance or backlash towards international organizations. Backlash is not mere criticism, but official statements that accuse and delegitimize institutions. IOs target of backlash were coded " 1 "; IOs that were not backlashed were coded " 0. " The condition is titled CONT. 
We collected information on 21 Latin American International Organizations and 10 Hemispheric Organizations (see Table 1), totaling 31 cases. The Latin American International Organizations are those with spatial/regional definition in their constitutive document, composed almost in all Latin American countries as member states. Hemispheric Organizations are those geographically limited to the Americas, including member states from the North, Central and South Americas, and The Caribbean. Considering the US political pressure on the continent and the emergence of middle powers, ${ }^{8}$ Hemispheric Organizations have been included in the models in order to find out if the absence of a dominant power/paymaster is associated with the paralysis of IOs in the Americas. Intercontinental and the Caribbean IOs have been excluded.

\section{RESULTS AND DISCUSSION}

We applied the QCA technique to evaluate whether conditions highlighted by the literature are (alone or in conjunction) necessary and/or sufficient for the presence/absence of the outcomes. We have not tested hypotheses/theories; rather, we used inductive/explorative reasoning to refine previous hypothesized conditions (Thomann and Maggetti 2020). We tried to identify patterns (pathways) considering that some conditions presented by the scholarship may only have explanatory power in conjunction with others (conjunctural causation), and that different configurations of conditions may lead to the same result (equifinality).

In order to analyze conditions favoring regular functioning or paralysis of the Latin American IOs, the QCA technique was applied to the cases. Software R, version 1.2.5033, combined with packages QCA (3.7) and SetMethods (2.6) was used. Firstly, we performed the analysis of necessity as follows:

Table 2 - Analysis of Necessity for Latin American IOs to remain active

\begin{tabular}{ccccc}
\hline & $\begin{array}{c}\text { Necessity } \\
\text { Inclusion (inclN) }\end{array}$ & $\begin{array}{c}\text { Relevance } \\
\text { of Necessity (RoN) }\end{array}$ & $\begin{array}{c}\text { Coverage of } \\
\text { Necessity (covN) }\end{array}$ \\
\hline 1 & STAFF + CSCOPE & 0.936 & 0.700 & 0.924 \\
\hline
\end{tabular}

Source: authors.

One configuration ${ }^{9}$ containing six explanatory conditions ${ }^{10}$ was set up. Testing for necessary conditions for the outcome (IO remain active) points out that

For a discussion on middle powers, see Cooper (1997), Chapnik (1999) and Flemes (2007).

Configuration and model are used interchangeably.

Organizational scope, quality of staff, number of states, level of statehood, political autonomy, and size of staff. See Appendix A. 
large staff (STAFF) or narrow organizational scope ( CSCOPE) are SUIN ${ }^{11}$ conditions for an IO in Latin America to remain active. SUIN conditions are those that are considered necessary conditions alternately, which means that at least one of them should be present for the outcome to occur. To have a regular functioning Latin American IO, it is necessary to either have broad staff or a restricted scope to compensate for low levels of personnel. This indicates that bureaucratic staff may be essential to explain why a Latin American IO remains active or paralyzes. Consistency and coverage measures are in accordance to recommended thresholds (Schneider and Wagemann 2012), both higher than 0.9 .

After testing for necessity, we performed an analysis of sufficiency to evaluate conditions or set of conditions leading to the Latin American IOs to remain active. Ragin (2008) indicates that thresholds should be higher than 0.75 . Thus, the analysis used thresholds above 0.8 . Tables 3 and 4 present the results.

Table 3 - Truth Table: causal paths leading to Latin American IOs remain active

\begin{tabular}{|c|c|c|c|c|c|c|c|c|c|c|}
\hline ڤి & 崖 & 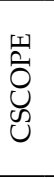 & $\begin{array}{l}\text { 岁 } \\
\text { 岁 } \\
0 \\
\text { U }\end{array}$ & 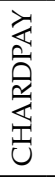 & 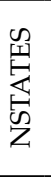 & 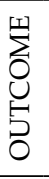 & $z$ & 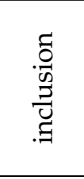 & $\begin{array}{l}\text { Proportional Reduction in } \\
\text { Inconsistency } \\
\text { (PRI) }\end{array}$ & cases \\
\hline 0 & 1 & 0 & 0 & 0 & 1 & 1 & 4 & 1.000 & 1.000 & IACI,IADefB,IAIAS,PAHO \\
\hline 0 & 1 & 1 & 0 & 0 & 0 & 1 & 2 & 1.000 & 1.000 & LAIA,PA \\
\hline 1 & 0 & 0 & 0 & 0 & 0 & 1 & 2 & 1.000 & 1.000 & COSAVE,ICRPBC \\
\hline 0 & 1 & 0 & 0 & 0 & 0 & 1 & 1 & 1.000 & 1.000 & CAIPA \\
\hline 0 & 1 & 1 & 0 & 0 & 1 & 1 & 1 & 1.000 & 1.000 & SICA \\
\hline 0 & 1 & 1 & 0 & 1 & 1 & 1 & 1 & 1.000 & 1.000 & SELA \\
\hline 0 & 1 & 1 & 1 & 0 & 0 & 1 & 1 & 1.000 & 1.000 & Andean \\
\hline 0 & 1 & 1 & 1 & 0 & 1 & 1 & 1 & 1.000 & 1.000 & OAS \\
\hline 1 & 0 & 0 & 0 & 0 & 1 & 1 & 1 & 1.000 & 1.000 & ASBLAC \\
\hline 1 & 1 & 0 & 0 & 0 & 0 & 1 & 1 & 1.000 & 1.000 & IATTC \\
\hline 1 & 1 & 0 & 0 & 0 & 1 & 1 & 1 & 1.000 & 1.000 & IAIC \\
\hline 1 & 1 & 1 & 1 & 0 & 0 & 1 & 1 & 1.000 & 1.000 & Mercosur \\
\hline 0 & 0 & 0 & 0 & 0 & 1 & 0 & 6 & 0.860 & 0.860 & $\begin{array}{l}\text { OPANAL,LACAC,LAE- } \\
\text { O,LAFDO,IACSS,PAIGH }\end{array}$ \\
\hline 0 & 0 & 0 & 0 & 0 & 0 & 0 & 3 & 0.815 & 0.815 & ATCO,LACP,LAIEC \\
\hline 0 & 0 & 1 & 1 & 0 & 0 & 0 & 1 & 0.718 & 0.718 & $\mathrm{AP}$ \\
\hline
\end{tabular}

11 SUIN is an acronym for "Sufficient but Unnecessary part of a factor that is Insufficient but Necessary for an outcome" (Mahoney 2008: 419). 


\begin{tabular}{|c|c|c|c|c|c|c|c|c|c|c|}
\hline 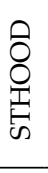 & 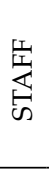 & 舀 & \begin{tabular}{l}
5 \\
\multirow{3}{3}{} \\
0 \\
8
\end{tabular} & 究 & 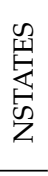 & $\begin{array}{l}\sum_{0}^{1} \\
0 \\
0 \\
0 \\
0\end{array}$ & $z$ & 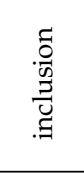 & $\begin{array}{l}\text { Proportional Reduction in } \\
\text { Inconsistency } \\
\text { (PRI) }\end{array}$ & cases \\
\hline 0 & 0 & 0 & 0 & 1 & 0 & 0 & 1 & 0.606 & 0.606 & BS \\
\hline 0 & 0 & 1 & 0 & 0 & 0 & 0 & 1 & 0.481 & 0.481 & Unasur \\
\hline 0 & 0 & 1 & 0 & 1 & 0 & 0 & 1 & 0.347 & 0.347 & Alba \\
\hline 0 & 0 & 1 & 0 & 1 & 1 & 0 & 1 & 0.163 & 0.163 & CELAC \\
\hline
\end{tabular}

Source: authors.

Table 4 - Analysis of Sufficiency: causal paths leading to Latin American IOs remaining active

\begin{tabular}{|c|c|c|c|c|c|}
\hline & & Cases & Consistency & $\begin{array}{c}\text { Raw Coverage } \\
(\operatorname{Cov} S)\end{array}$ & $\begin{array}{l}\text { Unique } \\
\text { Coverage } \\
\text { (CovU) }\end{array}$ \\
\hline 1 & STAFF* $\sim$ CHARDPAY & $\begin{array}{l}\text { CAIPA; IACI, IADefB, } \\
\text { IAIAS, PAHO, PA, SICA, } \\
\text { LAIA, Andean, OAS, IAIC, } \\
\text { IATTC, Mercosur. }\end{array}$ & 1.000 & 0.437 & 0.093 \\
\hline 2 & $\begin{array}{l}\sim \text { CSCOPE* } \sim \text { CHARD- } \\
\text { PAY }\end{array}$ & $\begin{array}{l}\text { ATCO, OPANAL, LACP, } \\
\text { LACAC, LAIEC, LAEO, LA- } \\
\text { FDO, IACSS, PAIGH, CAI- } \\
\text { PA, IACI, IADefB, IAIAS, } \\
\text { PAHO, COSAVE, ICRPBC, } \\
\text { ASBLAC, IAIC, IATTC. }\end{array}$ & 0.949 & 0.574 & 0.297 \\
\hline \multirow[t]{2}{*}{3} & $\begin{array}{l}\text { STAFF*CSCOPE*N- }^{*} \mathrm{~N} \\
\text { STATES }\end{array}$ & SICA, LAIA, SELA, OAS. & 1.000 & 0.147 & 0.022 \\
\hline & & & 0.961 & 0.756 & \\
\hline
\end{tabular}

Source: authors.

Note: Intermediate solution. Frequency cut-off: 1 . Consistency cut-off: 0.8 . Symbol $\sim$ means absence of the condition. Symbol * indicates logical connector "and." Numbers in bold refer to model's general measures of consistence and coverage.

After testing conditions, three paths proved sufficient for Latin American IOs to remain active: (1) large bureaucratic body (STAFF) and high quality of bureaucracy ( CHARDPAY); (2) narrow scope ( CSCOPE) and high quality of bureaucracy ( CHARDPAY), and (3) large bureaucratic body (STAFF), broad scope (CSCOPE) and a high number of member States (NSTATES). In this configuration, the level of statehood and political autonomy do not seem to be related to the functioning of the Latin American IOs.

The abovementioned results show that an adequate bureaucratic body is sufficient for a Latin American IO to remain active. Most cases are covered by paths 1 and 2. Path 1, which covers around 44\% of the cases, shows that large 
and high-quality staff is sufficient to sustain IO activities. Path 2, which covers around $57 \%$ of the cases, shows that high-quality staff combined with a restricted scope is sufficient to maintain regular functioning regardless of staff size. This is corroborated by its unique coverage of almost 0.14 , which means that this particular path can only explain $14 \%$ of the cases. It seems that very specialized organizations in the region are institutions that do not need many bureaucrats to keep their operations. Finally, if Latin American IOs deal with many different subjects (such as the Sistema de la Integración Centroamericana - SICA), it suffices to combine broad personnel and a high number of States to remain active. The legitimacy provided by the high number of members seems to compensate, for the SICA headquarter is not located in a competitive city, which may impose challenges to attract specialized professionals. In summary, the lack of adequate bureaucracy may be balanced either by restricting IOs' scope or by having a high number of member-states. The relevance of this model can be highlighted by its explanatory range, which covers the majority of cases analyzed (solution coverage $=0.756$ ).

In general, some of the conditions and directional expectations identified by the literature leading to the activity of an IO have also been identified in our model, mainly with regards to the bureaucracy (e.g. Debre and Dijkstra 2021; Gray 2018). Such results are not surprising, as "less attractive secretariat cities (the more hardship compensation offsetting the locale) are associated with less vitality, and there is a positive association with death [of organizations] (Gray 2018:09) ". Bureaucrats have an agency, they work on the development and implementation of IO activities, and accumulate authority and political experience (Barnett and Finnemore 2004). They significantly contribute to creating an international policy, administrative reforms, and organizational changes (Ege and Bauer 2013). Ultimately, it is of the bureaucrats' personal interest to maintain their jobs, contributing to the regular functioning of the IOs. The quality of staff can only be bypassed in bigger settings: organizations with a high number of employees, deal with various subjects, and have high membership. The typical case is OAS. Moreover, only four IOs functioning regularly do not incorporate high quality employees in the setting that explains the outcome. We call this the high-quality staff effect.

After finding the necessary and sufficient paths that explain the outcome "Active", the paper now uses the same conditions to test for the negation of the outcome: paralysis. IR scholarship tends to claim that IO paralysis results from the lack of those conditions that explain activity. Results are depicted in Tables 5 and 6 . 
Table 5 - Truth Table: causal paths leading to the paralysis of Latin American IOs

\begin{tabular}{|c|c|c|c|c|c|c|c|c|c|c|}
\hline 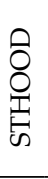 & 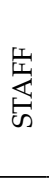 & 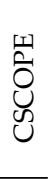 & 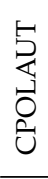 & 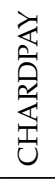 & 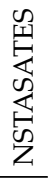 & 占 & Z & 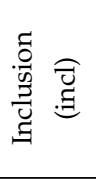 & $\begin{array}{l}\text { Proportional } \\
\text { Reduction in } \\
\text { Inconsistency } \\
\quad(\text { PRI) }\end{array}$ & cases \\
\hline 0 & 0 & 1 & 0 & 1 & 1 & 1 & 1 & 0.810 & 0.810 & CELAC \\
\hline 0 & 0 & 0 & 0 & 0 & 1 & 0 & 8 & 0.148 & 0.148 & $\begin{array}{c}\text { OPANAL,LACP,LACAC,LAIEC,LAE- } \\
\text { O,LAFDO,IACSS,PAIGH }\end{array}$ \\
\hline 0 & 1 & 0 & 0 & 0 & 1 & 0 & 4 & 0.000 & 0.000 & IACI,IADefB,IAIAS,PAHO \\
\hline 0 & 1 & 1 & 0 & 0 & 1 & 0 & 2 & 0.000 & 0.000 & SICA,LAIA \\
\hline 1 & 0 & 0 & 0 & 0 & 0 & 0 & 2 & 0.000 & 0.000 & COSAVE,ICRPBC \\
\hline 1 & 1 & 0 & 0 & 0 & 1 & 0 & 2 & 0.000 & 0.000 & IAIC,IATTC \\
\hline 0 & 0 & 0 & 0 & 0 & 0 & 0 & 1 & 0.157 & 0.157 & ATCO \\
\hline 0 & 0 & 0 & 0 & 1 & 0 & 0 & 1 & 0.452 & 0.452 & BS \\
\hline 0 & 0 & 1 & 0 & 0 & 1 & 0 & 1 & 0.661 & 0.661 & Unasur \\
\hline 0 & 0 & 1 & 0 & 1 & 0 & 0 & 1 & 0.696 & 0.696 & Alba \\
\hline 0 & 0 & 1 & 1 & 0 & 0 & 0 & 1 & 0.285 & 0.285 & $\mathrm{AP}$ \\
\hline 0 & 1 & 0 & 0 & 0 & 0 & 0 & 1 & 0.000 & 0.000 & CAIPA \\
\hline 0 & 1 & 1 & 0 & 0 & 0 & 0 & 1 & 0.000 & 0.000 & PA \\
\hline 0 & 1 & 1 & 0 & 1 & 1 & 0 & 1 & 0.000 & 0.000 & SELA \\
\hline 0 & 1 & 1 & 1 & 0 & 0 & 0 & 1 & 0.000 & 0.000 & Andean \\
\hline 0 & 1 & 1 & 1 & 0 & 1 & 0 & 1 & 0.000 & 0.000 & OAS \\
\hline 1 & 0 & 0 & 0 & 0 & 1 & 0 & 1 & 0.000 & 0.000 & ASBLAC \\
\hline 1 & 1 & 1 & 1 & 0 & 0 & 0 & 1 & 0.000 & 0.000 & Mercosur \\
\hline
\end{tabular}

Source: authors.

Table 6 - Analysis of Sufficiency: causal paths leading to the paralysis of Latin American IOs

\begin{tabular}{lcccc}
\hline & Cases & Consistency & $\begin{array}{c}\text { Raw Coverage } \\
(\text { CovS })\end{array}$ & $\begin{array}{c}\text { Unique Covera- } \\
\text { ge (CovU) }\end{array}$ \\
\hline $1 \begin{array}{l}\sim \text { STHOOD }^{*} \sim \text { STAFF }^{*} \sim \text { CPOLAUT }^{*}- \\
\text { CHARDPAY NSTATES2 }^{*} \text { CELAC }\end{array}$ & 0.422 & 0.352 & - \\
\hline & $\mathbf{0 . 4 2 2}$ & $\mathbf{0 . 3 5 2}$ & \\
\hline
\end{tabular}

Source: authors.

Note: Intermediate solution. Frequency cut-off: 1 . Consistency cut-off: 0.8 . Symbol $\sim$ means absence of the condition. Symbol * indicates logical connector "and." Numbers in bold refer to model's general measures of consistence and coverage. 
Despite the symmetrical idea theorized by the literature, the results show that this is not the case. The model did not offer significant results that support this argument. Although showing a possible path to explain CELAC's paralysis, the low consistency rate of 0.422 (below the 0.8 threshold) undermines this explanation. Additionally, it would explain only $35 \%$ of the cases $(0.352) .{ }^{12}$ Therefore, factors pointed out by the literature do not seem to be conducive to the paralysis of IOs in Latin America.

Regarding QCA, not having results for non-occurrence it is not considered a problem due to asymmetrical causation (Schneider and Wagemann 2012). The technique supports causal paths non-deterministically, in which $X \rightarrow Y$ differs from If $Y$, so $X$ occurred. That is, causality does not imply that the absence of $X$ necessarily leads to $Y^{\prime}$ 's absence, since $Y$ may be the result of other conditions or sets of conditions. Thus, Schneider and Wagemann (2012) recommend looking for different theoretical frameworks for different outcomes. The hypothesis is that the paralysis of the Latin American IOs follows different patterns than indicated by the literature.

A factor usually posed by scholars is the presence/absence of a paymaster. This argument is well-developed by International Organization literature (Börzel and Risse 2016; Tallberg et al. 2016), as this particular State would have sufficient capacity to absorb cooperation costs, being a critical element to foster the functioning of IOs. Hence, another configuration was tested, combining the previous six conditions ${ }^{13}$ with a condition called "POWER", which indicates the presence of a paymaster/dominant power. The second model also did not present relevant results, indicating that the absence of a dominant power - alone or in conjunction with other conditions - is not empirically meaningful for the outcome paralysis of IOs in Latin America. Results are in line with Petersen and Schulz's conclusions, in which the US presence - the dominant power of the American continent - does not affect cooperation initiatives among the Latin American countries (Petersen and Schulz 2018).

A third configuration was evaluated, by adding the condition Contestation (CONT). It intends to comprehend whether being contested represents a factor that may explain paralysis in combination with other elements. Nationalism and populism have been identified as a problem for IOs, as they tend to oppose deeper international cooperation (Copelovitch and Pevehouse 2019). On the other hand, these factors seem to be linked to a recent wave of institutional backlash, but they are not sufficient to analyze contestation of IOs - specifically withdraw from IOs - for the long-term (Von Borzyskowski and Vabulas 2019).

12 It is worth noting that, different from consistency, there is no consensus with regard to a coverage threshold in QCA literature.

13 An important caveat regarding bringing a new condition to the model: on the one hand, adding more conditions helps reduce contradictory rows and specify the analysis; on the other hand; it increases the number of logical remainders, which could lead to a limited diversity problem (Schneider; Wagemann, 2010). Aware of the problems it may present to the analysis, we balanced the pros and cons, and decided to expand the model despite this challenge. 
Contestation is also linked to the relationship between members, which may diverge ideologically, making member states less likely to cooperate, and giving a hard time to IOs (Dijkstra 2019). Ideological issues play an important role in the functioning of IOs, as the change in government orientation increases the possibility of States withdrawing from IOs by 74\% (von Borzyskowski and Vabulas 2019). According to Von Borzyskowski and Vabulas (2019: 351), "when an election has just occurred, and a different government is in power, the new government may be more likely to withdraw from an IGO to follow through on a mandate, or because it represents changed sentiments toward international commitments."

Thus, we performed a new model with this condition due to specific features of the Latin American regionalism, where IOs frequently emerge due to momentary ideological coincidences among leaders and parties (Gardini 2015; Malamud and Gardini 2012; Sanahuja 2012). Petersen and Schulz (2018: 120) argue that "shifts in the regional agenda are best explained as periods of ideological convergence." For instance, at the beginning of the XXI century, the Latin American governments created new institutions as a result of occasional ideological convergences, either among leftist parties (2000s and 2010s) or rightist parties (mid 2010s onwards).

When there is discontinuity among leaders' ideologies, the new ones tend to contest the predecessor's foreign policy, including their inclinations towards certain international institutions. It is possible to see this type of contestation coming from leaders that contested institutions considered ideologically biased, ${ }^{14}$ which may lead to resistance - defined by the literature as backlash (Copelovitch and Pevehouse 2019; Madsen, Cebulak, and Wiebusch 2018).

Some of these contestations may lead to radical outcomes such as withdrawing from the organization. In Latin America, the case of the Inter-American Human Rights Court is illustrative. During the 1990s, 2000s and 2010s, some Latin American countries withdrew from that Court, normally using harsh arguments to justify their exiting. For instance, among the Venezuelan justifications to exit the Court, it accused the tribunal of serving as an instrument of American imperialism - Venezuela also withdrew from the OAS using similar rhetoric (Soley and Steininger 2018). In the late 2010s, at the end of the pink tide, organizations like Unasur, Alba, Celac were targets of ideologically biased accusations, and longer-lived organizations like Mercosur and Andean received severe criticism. According to Contesse (2019: 24) "because such decisions [of withdrawing from IOs] are usually accompanied by strong criticism against the treaty regime when a state exits, a state's withdrawal can cause harm to the system's overall stability." Recently, literature has also focused on contestation against IOs in general, even concluding that "there appears to be some clearly

14 This was the case of regional institutions such as OAS, Inter-American Human Rights Commission, and Inter-American Human Rights Court, contested by leaders like Hugo Chaves, who accused them as an instrument of the US imperialism. 
articulated ideological pattern in the de-legitimating of IOs" (Hooghe, Lenz, and Marks 2019:740). Depending on the challenge, and how it frames its arguments, it may lead the IO to paralysis. ${ }^{15}$

The third configuration was evaluated combining the six original conditions with $\mathrm{CONT},{ }^{16}$ and consistent results were found (Consistency $=1.00$ ), covering $64 \%$ of the cases, as presented in Tables 7 and 8 below.

Table 7 - Truth Table: causal paths leading to the paralysis of Latin American IOs

\begin{tabular}{|c|c|c|c|c|c|c|c|c|c|c|c|}
\hline 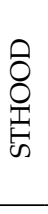 & $\underset{\omega}{\stackrel{4}{\leftrightarrows}}$ & 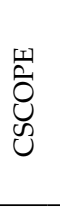 & $\begin{array}{l}5 \\
\text { 岕 } \\
0 \\
0 \\
0\end{array}$ & 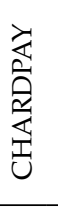 & 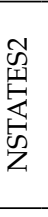 & 艺 & 5 & $=$ & $\begin{array}{l}\text { Inclusion } \\
\quad \text { (incl) }\end{array}$ & $\begin{array}{c}\text { Propor- } \\
\text { tional } \\
\text { Reduction } \\
\text { in Inconsis- } \\
\text { tency } \\
\text { (PRI) } \\
\end{array}$ & cases \\
\hline 0 & 0 & 0 & 0 & 0 & 1 & 0 & 1 & 8 & 0.871 & 0.871 & $\begin{array}{l}\text { OPANAL,LACP,LACAC,LAIEC, } \\
\text { LAEO,LAFDO,IACSS,PAIGH }\end{array}$ \\
\hline 0 & 1 & 0 & 0 & 0 & 1 & 0 & 1 & 4 & 1.000 & 1.000 & IACI,IADefB,IAIAS,PAHO \\
\hline 0 & 1 & 1 & 0 & 0 & 1 & 0 & 1 & 2 & 1.000 & 1.000 & SICA,LAIA \\
\hline 1 & 0 & 0 & 0 & 0 & 0 & 0 & 1 & 2 & 1.000 & 1.000 & COSAVE,ICRPBC \\
\hline 1 & 1 & 0 & 0 & 0 & 1 & 0 & 1 & 2 & 1.000 & 1.000 & IAIC,IATTC \\
\hline 0 & 0 & 0 & 0 & 0 & 0 & 0 & 1 & 1 & 0.890 & 0.890 & ATCO \\
\hline 0 & 0 & 1 & 1 & 0 & 0 & 0 & 1 & 1 & 1.000 & 1.000 & $\mathrm{AP}$ \\
\hline 0 & 1 & 0 & 0 & 0 & 0 & 0 & 1 & 1 & 1.000 & 1.000 & CAIPA \\
\hline 0 & 1 & 1 & 0 & 0 & 0 & 0 & 1 & 1 & 1.000 & 1.000 & PA \\
\hline 0 & 1 & 1 & 0 & 1 & 1 & 0 & 1 & 1 & 1.000 & 1.000 & SELA \\
\hline 0 & 1 & 1 & 1 & 0 & 0 & 0 & 1 & 1 & 1.000 & 1.000 & Andean \\
\hline 0 & 1 & 1 & 1 & 0 & 1 & 1 & 1 & 1 & 1.000 & 1.000 & OAS \\
\hline 1 & 0 & 0 & 0 & 0 & 1 & 0 & 1 & 1 & 1.000 & 1.000 & ASBLAC \\
\hline 1 & 1 & 1 & 1 & 0 & 0 & 0 & 1 & 1 & 1.000 & 1.000 & Mercosur \\
\hline 0 & 0 & 0 & 0 & 1 & 0 & 1 & 0 & 1 & 0.000 & 0.000 & BS \\
\hline 0 & 0 & 1 & 0 & 0 & 1 & 1 & 0 & 1 & 0.000 & 0.000 & Unasur \\
\hline 0 & 0 & 1 & 0 & 1 & 0 & 1 & 0 & 1 & 0.000 & 0.000 & Alba \\
\hline 0 & 0 & 1 & 0 & 1 & 1 & 1 & 0 & 1 & 0.000 & 0.000 & CELAC \\
\hline
\end{tabular}

Source: authors.

15 For instance, the Trump administration has managed to block the World Trade Organization Appellate Body by not indicating a new member for the organ. See: https://www.nytimes.com/2019/12/08/ business/trump-trade-war-wto.html

16 Organizational scope, quality of staff, number of states, level of statehood, political autonomy, size of the staff, and contested IO. See Appendix A. 
Table 8 - Model 3: analysis of Sufficiency and causal paths leading to the paralysis of Latin American IOs

\begin{tabular}{|c|c|c|c|c|c|}
\hline & & Cases & Consistency & $\begin{array}{c}\text { Raw Coverage } \\
(\operatorname{Cov} S)\end{array}$ & $\begin{array}{l}\text { Unique Cove- } \\
\text { rage (CovU) }\end{array}$ \\
\hline \multirow[t]{2}{*}{1} & $\begin{array}{c}\sim \mathrm{STHOOD}^{*} \sim \mathrm{STAFF}^{*} \sim \mathrm{CPOLAU}- \\
\mathrm{T}^{*} \mathrm{CONT}\end{array}$ & $\begin{array}{l}\text { BS, Unasur, } \\
\text { Alba, CELAC }\end{array}$ & 1.00 & 0.640 & - \\
\hline & & & 1.00 & 0.640 & \\
\hline
\end{tabular}

Source: authors.

Note: Intermediate solution. Frequency cut-off: 1 . Consistency cut-off: 0.8 . Symbol means absence of the condition. Symbol * indicates logical connector "and." Numbers in bold refer to model's general measures of consistence and coverage.

Configuration 3 resulted in a single set of conditions associated with the paralysis of IOs in Latin America: low level of statehood ( STHOOD), small staff ( STAFF), low political autonomy ( CPOLAUT), and IO contested by member states (CONT). It explains 4 cases of paralysis: Bank of the South, Unasur, Alba, and CELAC, four organizations with their roots grounded, at least to a certain degree, in ideological affinities (Gardini 2015; Sanahuja 2012).

Given Latin America's right turn in the 2010s (Argentina, Brazil, Chile, and Peru, for example), the slow recovery from the effects of the economic crisis, the worsening of the Venezuelan crisis, coupled with a perception that part of the regional organizations created during the 2000 - 2014 period were linked to a purely ideological agenda have led to a crisis in Latin American regionalism. The Pacific Alliance - created in 2011 as a counterpoint to the Union of South American Nations model - proved to be an important milestone at the end of the pink tide, when the leftist convergence in South America seemed to run out. In 2019, the Forum for the Progress and Development of South America (Prosur) was announced with the participation of several South American countries, which had elected right-wing governments in the 2010s. They have established a forum to create another regional organization, now aligned with the political ideas prevailing in part of the continent, an arena clearly aimed at opposing Unasur (Calderon 2019), but that also rivals Mercosur. We labelled this contestation effect.

Nonetheless, although Contestation seems to play an important role in explaining paralysis, it is just an INUS condition, an Insufficient but Necessary part of a condition that is in itself Unnecessary, but Sufficient for the outcome. This means that it can only have explanatory power when combined with other conditions (Schneider and Wagemann 2012). As an INUS condition, Contestation can explain the outcome only when combined with other elements - this is a clear example of conjunctural causation. In this case, it needed to appear in conjunction with weak institutional characteristics - namely low political autonomy and small bureaucratic staff - and also with external factors such as a low average level of statehood of member states. Without these other INUS conditions, the contestation alone would not lead IO paralysis. More robust 
bureaucracy and more institutionalization would have prevented contestations from halting $\mathrm{IO}$ operations.

\section{CONCLUSION}

As the literature has shown various elements that would explain the activity/ paralysis of Latin American IOs, which are non-exclusive in kind, we decided to apply Qualitative Comparative Analysis to search for possible factors that would explain these outcomes. In summary, we identified explanatory variables in the literature and considered them non-exclusive conditions to be evaluated in conjunction. Using QCA, the paper then sought conditions or a set of conditions that would lead to the functioning and paralysis of IOs in the region.

The results presented in the analysis showed that the general literature on the functioning of IOs is robust in identifying the elements that lead to Latin American organizations remaining active. Staff size, bureaucracy quality, and the reduced scope are essential conditions for a Latin American IO to function. In addition, the combination of large teams, broad organizational scopes, and a large number of member states produce an active organization. It could be seen that the main explanation for Latin American IOs functioning was related to the so called 'high-quality staff effect'.

These results are relevant because they highlight associations between explanatory conditions and expected results, as QCA presents its relations of necessity and sufficiency. However, it does not exclude the need for further studies on causal mechanisms operating in the issue, especially for cases not covered by the models. The findings also demonstrated that some conditions theorized by the literature as explanatory elements for activity/paralysis appear not to have empirical relevance. Specifically, the models showed that conditions of level of statehood and political autonomy are not related to the functioning of Latin American IOs.

QCA analysis also indicated that literature has limitations in identifying the conditions or set of conditions for the paralysis of IOs in Latin America. From the first six conditions evaluated, no single one - or set thereof - was found sufficient to lead to the paralysis of the organizations. Thus, both general studies and specific regional analyses seem to be inadequate to detect the elements that make Latin American IOs stop regular functioning. A preliminary conclusion is that the literature failed in this evaluation because it seeks to identify causality of paralysis from the negation of conditions that lead to its functioning, based on the understanding that the absence of the elements of "success" would lead to "failure." However, the findings indicate that this is not an adequate way to evaluate paralysis. In other words, the models point to asymmetrical causation in this regard.

In order to capture other possible explanations, we evaluated two more configurations, adding two conditions that are relevant to the Latin American sce- 
nario: dominant power/paymaster and political contestation. The model that included dominant/paymaster power did not generate causal paths with satisfactory consistency and coverage measures, implying that the absence of this condition was not fundamental for an IO to paralyze. In Latin America, the costs of cooperation appear to be absorbed in other ways so that the absence of an actor that exercises clear leadership in the organization does not necessarily lead to the non-functioning of the IO.

Only the model with the political contestation condition (CONT) generated necessary and sufficient paths for the outcome paralysis. However, the contestation effect operates only when it is combined with other three conditions: low level of statehood in the member states, small staff, and low political autonomy.

Finally, the results (Tables 6, 7 and 8) evince that the paralysis of Latin American IOs cannot be credited to an isolated factor, but to a complex combination of conditions. Such results are critical to oppose interpretations that indicate a single factor (lack of statehood, for example) as the roots of paralysis of Latin American IOs or treat the issue as "wicked problems." Moreover, these results open a research agenda to clarify the role of each condition in the paralysis of IOs in the region.

In general, our analysis points to two main theoretical directions for further studies: 1) more attention should be devoted to the role of bureaucracies for the functioning of Latin American IOs, and 2) more theoretical thinking is needed to understand paralysis with regards to these institutions.

\section{REFERENCES}

Barnett, Professor of Political Science Michael, and Martha Finnemore. 2004. Rules for the World: International Organizations in Global Politics. Ithaca, N.Y: Cornell University Press.

Basurto, Xavier and Johanna Speer. 2012. "Structuring the Calibration of Qualitative Data as Sets for Qualitative Comparative Analysis (QCA)". Field Methods 24(2): 155-74.

Berg-Schlosser, Dirk, Gisele De Meur Benoit Rihoux and Charles Ragin. 2008. "Qualitative comparative analysis (qca) as an approach." In Configurational Comparative Methods: Qualitative comparative analysis (QCA) and related techniques. London: SAGE Publications, Inc.

Börzel, Tanja A. and Thomas Risse. 2016. The Oxford Handbook of Comparative Regionalism. Oxford University Press.

von Borzyskowski, Inken, and Felicity Vabulas. 2019. "Hello, Goodbye: When Do States Withdraw from International Organizations?" The Review of International Organizations 14(2): 335-66.

Buelvas, Eduardo Pastrana. 2013. "Why Regionalism Has Failed in Latin America: Lack of Stateness as an Important Factor for Failure of Sovereignty Transfer in Integration Projects". Contexto Internacional 35: 443-69.

Calderon, Jesus Barrancos. 2019. Principios de geopolitica y geoeconomia boliviana en America del Sur. Master's Thesis, Unila. https://dspace.unila.edu.br/handle/123456789/5088

Chapnik, Adam. 1999. “The Middle Power". Canadian Foreign Policy 7: 73-82. 
Contesse, Jorge. 2019. "Resisting the Inter-American Human Rights System." Yale Journal of International Law 44: 179-237.

Cooper, Andrew. 1997. Niche Diplomacy: Middle Powers After the Cold War. London: Macmillan. Copelovitch, Mark, and Jon C. W. Pevehouse. 2019. "International Organizations in a New Era of Populist Nationalism". The Review of International Organizations 14(2): 169-86.

Debre, Maria Josepha and Hylke Dijkstra. 2021. "Institutional design for a post-liberal order: why some international organizations live longer than others". European Journal of International Relations 27(1): 311-39.

Dijkstra, Hylke. 2019. "Who gets to live forever? An Institutional Theory on the Life and Death of International Organizations." In ECPR Joint Sessions, Mons, 8-12 April 2019. http:/ / www.nestior.eu

Ege, Jörn, and Michael W. Bauer. 2013. "International bureaucracies from a Public Administration and International Relations perspective". In Routledge Handbook of International Organization, Routledge.

Eilstrup-Sangiovanni, Mette. 2020. "Death of International Organizations. The Organizational Ecology of Intergovernmental Organizations, 1815-2015". The Review of International Organizations 15(2): 339-70.

Finnemore, Martha. 1996. National Interests in International Society. $1^{\mathrm{a}}$ edition. Ithaca, N.Y: Cornell University Press.

Flemes, Daniel. 2007. "Emerging Middle Powers' Soft Balancing Strategy: State and Perspectives of the IBSA-Dialogue Forum". GIGA Working Paper 57. Hamburg: German Institute of Global and Area Studies.

Gallarotti, Giulio M. 1991. "The Limits of International Organization: Systematic Failure in the Management of International Relations". International Organization 45(2): 183-220.

Garcés Velástegui, Pablo. 2017. "Latin American Integration as a Wicked Problem: The Case for a Plural Approach". Revista Relaciones Internacionales, Estrategia y Seguridad 13(1): 93-117.

Gardini, Gian Luca. 2015. “Towards Modular Regionalism: The Proliferation of Latin American Cooperation". Revista Brasileira de Política Internacional 58: 210-29.

Grävingholt, Jörn, Sebastian Ziaja, and Merle Kreibaum. 2012. "State Fragility: Towards a Multi-Dimensional Empirical Typology". SSRN Electronic Journal. http://www.ssrn. com/abstract=2279407 (8 December 2021).

Gray, Julia. 2018. "Life, Death, or Zombie? The Vitality of International Organizations". International Studies Quarterly 62(1): 1-13.

Haas, Professor Ernst B. 1964. Beyond the Nation-State: Functionalism and International Organization. Revised ed. Stanford, Calif: Stanford University Press.

Haftel, Yoram Z. 2012. Regional Economic Institutions and Conflict Mitigation: Design, Implementation, and the Promise of Peace. Ann Arbor: University of Michigan Press.

Hooghe, Liesbet, Tobias Lenz, and Gary Marks. 2019. “Contested World Order: The Delegitimation of International Governance". The Review of International Organizations 14(4): $731-43$.

Keohane, Robert O. 2005. After Hegemony: Cooperation and Discord in the World Political Economy. Revised edition. Princeton, N.J: Princeton University Press.

Lohaus, Mathis and Felix Hummel. 2012. "MERCOSUR: Integration through Presidents and Paymasters." In Börzel, Tanja A. et al. (ed). Roads to Regionalism - Genesis, Design, and Effects of Regional Organizations. Farnham: Ashgate.

Madsen, Mikael Rask, Pola Cebulak, and Micha Wiebusch. 2018. "Backlash against International Courts: Explaining the Forms and Patterns of Resistance to International Courts". International Journal of Law in Context 14(2): 197-220.

Mahoney, James. 2008. "Toward a Unified Theory of Causality". Comparative Political Studies 41: 412-36.

Malamud, Andrés. 2019. “Overlapping Regionalism, No Integration: Conceptual Issues and The Latin American Experiences". Politica Internacional: 46-59.

Malamud, Andrés and Gian Luca Gardini. 2012. "Has Regionalism Peaked? The Latin American Quagmire and its Lessons". The International Spectator 47(1): 116-33. 
Marx, Axel. 2010. "Crisp-set qualitative comparative analysis (csQCA) and model specification: Benchmarks for future csQCA applications". International Journal of Multiple Research Approaches 4(2): 138-58.

Mattli, Walter. 1999. The Logic of Regional Integration: Europe and Beyond. Cambridge: Cambridge University Press. https://www.cambridge.org/core/books/logic-of-regional-integration/1001F7BE284C55D67F3B3F34E7D6F1F1 (8 December 2021).

Mearsheimer, John J. 1994. "The False Promise of International Institutions". International Security 19(3): 5-49.

Mockaitis, Audra I., Lena Zander, and Helen De Cieri. 2018. “The Benefits of Global Teams for International Organizations: HR Implications". International Journal of Human Resource Management 29(14): 2137-58.

Panke, Diana and Anna Starkmann. 2021. “Trajectories of Regional Cooperation: A Comparative Analysis". Comparative European Politics 19(1): 1-25.

Petersen, Mark and Carsten-Andreas Schulz. 2018. "Setting the Regional Agenda: A Critique of Posthegemonic Regionalism". Latin American Politics and Society 60(1): 102-27.

Pevehouse, Jon, Timothy Nordstrom, and Kevin Warnke. 2004. "The Correlates of War 2 International Governmental Organizations Data Version 2.0". Conflict Management and Peace Science 21(2): 101-19.

Quiliconi, Cintia and Raúl Salgado Espinoza. 2017. "Latin American Integration: Regionalism Àla Carte in a Multipolar World?" Colombia Internacional (92): 15-41.

Ragin, Charles C. 2008. Redesigning Social Inquiry: Fuzzy Sets and Beyond. Illustrated edição. Chicago: University of Chicago Press.

Rubinson, Claude. 2019. "Presenting Qualitative Comparative Analysis: Notation, Tabular Layout, and Visualization". Methodological Innovations 12(2): 205979911986211.

Sanahuja, Jose Antonio. 2012. Post-Liberal Regionalism in South America: The Case of UNASUR. . Working Paper. https:/ / cadmus.eui.eu//handle/1814/20394 (8 December 2021).

Schneider, Carsten. Q. and Wagemann, Claudius. 2010. "Standards of Good Practice in Qualitative Comparative Analysis (QCA) and Fuzzy-Sets", Comparative Sociology, 9:3, 397418.

Schneider, Carsten Q. and Claudius Wagemann. 2012. Set-Theoretic Methods for the Social Sciences: A Guide to Qualitative Comparative Analysis. Cambridge: Cambridge University Press. https://www.cambridge.org/core/books/settheoretic-methods-for-the-social-sciences/236C162386C1188966FE269D625CA289 (8 December 2021).

Soley, Ximena and Silvia Steininger. 2018. "Parting Ways or Lashing Back? Withdrawals, Backlash and the Inter-American Court of Human Rights". International Journal of Law in Context 14(2): 237-57.

Tallberg, Jonas, Thomas Sommerer, Theresa Squatrito, and Magnus Lundgren. 2016. "The performance of international organizations: a policy output approach". Journal of European Public Policy 23(7): 1077-96.

Thomann, Eva and Martino Maggetti. 2020. "Designing Research With Qualitative Comparative Analysis (QCA): Approaches, Challenges, and Tools". Sociological Methods $\mathcal{E}$ Research 49(2): 356-86.

Wallace, Michael and J. David Singer. 1970. "Intergovernmental Organization in the Global System, 1815-1964: A Quantitative Description". International Organization 24(2): 239_ 87.

Zaytsev, Dmitry. 2013. "Indices of "Stateness" and Governance: Damaging Fallacies and Possibly Optimizing Choices." Paper presented at the International Conference

on Public Policy, Grenoble.. Retrived August 31, 2021 from International Publica Policy Association, at: http://www.icpublicpolicy.org/.../panel_9_s_1_zaytsev.pdf .

Received: January 4, 2021

Accepted: December 18, 2021 
Mariana P. O. de Lyra is an Assistant Professor of International Relations in the Department of International Relations at the University for International Integration of the Afro-Brazilian Lusophony. She studies international organizations, security, and defense in Latin America. Recent publications include "The Use of Force Should Not Be Our First, But Our Last Option" (Global Society, 2020, co-authorship with M. Ribeiro and R. Mesquita), and Política Internacional Contemporânea: questões estruturantes e novos olhares (Eduft, 2020, co-authorship with J. Larcerda and M. Ribeiro). Email: marianalyra@unilab.edu.br

Mikelli Marzzini L. A. Ribeiro is an Assistant Professor of International Relations in the Department of Political Science, Federal University of Pernambuco - UFPE (Recife, Brazil). He is a fellow of the Civil Wars Path Project (Sheffield University) and the Brazilian Research Network on Peace Operations. His research focuses on international organizations, security, and human rights. Recent publications include "The Use of Force Should Not Be Our First, But Our Last Option" (Global Society, 2020, co-authorship with M. Lyra and R. Mesquita). and China's engagement with R2P: pluralist shaper? (Global Responsibility to Protect, 2020, co-authorship with M. Medeiros and A. Leite). Email: mikelli.lucas@ufpe.br 